\title{
Struktur Vertikal Distribusi Butiran Hujan di Kototabang Berdasarkan Pengamatan Micro Rain Radar (MRR)
}

\author{
Indah Rahayu $^{1}$, Marzuki ${ }^{1 *}$, Hiroyuki Hashiguchi ${ }^{2}$, Toyoshi Shimomai ${ }^{3}$ \\ ${ }^{1}$ Jurusan Fisika FMIPA Universitas Andalas, Padang, ${ }^{2}$ RISH Universitas Kyoto, Jepang, \\ ${ }^{3}$ Interdisciplinary Faculty of Science and Engineering, Shimane University, Jepang \\ *marzuki@fmipa.unand.ac.id
}

\begin{abstract}
ABSTRAK
Distribusi ukuran butiran hujan atau raindrop size distribution (RDSD) arah vertikal dari ketinggian 0,15 km hingga 4,65 km di Kototabang, Sumatera Barat, telah diteliti melalui pengamatan Micro Rain Radar (MRR) selama Januari-Desember 2012. Intensitas curah hujan (rainfall rate) dari Optical Rain Gauge (ORG) dan RDSD dari Parsivel digunakan untuk menguji kinerja MRR. Pengujian memperlihatkan bahwa MRR berfungsi dengan baik dimana intensitas curah hujan dari ORG berkorelasi dengan baik dengan MRR ( $\mathrm{r}=0,98)$ dan RDSD dari MRR secara umum juga memperlihatkan pola dan nilai yang sama dengan yang didapatkan Parsivel. Selanjutnya, RDSD dari MRR dimodelkan dengan distribusi gamma dan parameternya didapatkan menggunakan metode momen. Terlihat bahwa pertumbuhan RDSD di Kototabang dari ketinggian 4,65 km hingga 0,15 km sangat kuat yang kemungkinan disebabkan oleh proses tumbukan-penggabungan. Hal ini ditandai dengan peningkatan konsentrasi butiran berukuran besar dengan penurunan ketinggian. Peningkatan konsentrasi butiran hujan berukuran besar terhadap penurunan ketinggian berpengaruh kepada parameter-parameter hujan seperti radar reflectivity $(Z)$ dan rainfall rate $(R)$ yang menyebabkan peningkatan koefisien $A\left(Z=A R^{b}\right)$ terhadap penurunan ketinggian. Dengan demikian, penggunaan persamaan $Z-R$ yang konstan untuk setiap ketinggian bagi radar meteorologi di kawasan tropis khususnya Sumatera Barat tidak tepat.

Kata kunci: raindrop size distribution, MRR, Kototabang, distribusi gamma.
\end{abstract}

\begin{abstract}
Vertical structure of raindrops size distribution (RDSD) as retrieved by Micro Rain Radar (MRR) during January-December 2012 at Kototabang, west Sumatera had been investigated. The performance of MRR was examined by comparing the rainfall rate $(R)$ and RDSD obtained by the MRR with that obtained by the Optical Rain Gauge (ORG) and Parsivel, respectively. It was found that the data of MRR were in good agreement with those of ORG and Parsivel. Thus, the MRR at Kototabang collected precipitation data in good accuracy. The RDSD was parameterized by modified gamma distribution and its parameter was calculated by the moment method. It was found that the growth of RDSD from the altitude of $4.65 \mathrm{~km}$ to $0.15 \mathrm{~km}$ was significant that may be due to the collision-induced coalescence process. This can be inferred from a significant increase of large-sized drops with decreasing height. The increase of such drops influenced the integral rainfall parameters such as radar reflectivity $(Z)$ and $R$ that leads to an increase of $A$ coefficient of $Z=A R b$ equation with decreasing height. Thus, the usage of constant Z-R equation in rain column for radar meteorology in tropical regions particularly in West Sumatra, are not acceptable.
\end{abstract}

Keywords: raindrop size distribution, MRR, Kototabang, gamma distribution.

\section{PENDAHULUAN}

Distribusi butiran hujan atau yang sering disebut raindrop size distribution (RDSD) adalah distribusi butiran hujan dengan ukuran tertentu per volume sampel pengamatan selama interval waktu tertentu (Jameson dan Kostinski, 2001). RDSD sangat penting dalam bidang telekomunikasi menggunakan gelombang mikro (Marzuki dkk., 2009). Selain itu RDSD juga penting bagi radar dan satelit meteorologi (Coppens dan Haddad, 2000). Selanjutnya RDSD penting dibidang fisika awan (Tokay dan Short, 1996).

Mengingat pentingnya RDSD, telah banyak alat yang dikembangkan untuk pengamatannya. Pengamatan RDSD di permukaan tanah telah dilakukan dengan berbagai tipe disdrometer seperti Joss dan Waldvogel disdrometer (Joss dan Waldvogel, 1969), particle size velocity (parsivel) (Loffler-Mang dan Joss, 2000) dan two dimensional video disdrometer (Kruger dan Krajewski, 2002). Selain di permukaan tanah, juga telah dilakukan pengamatan struktur vertikal RDSD. Struktur vertikal RDSD dapat dimanfaatkan untuk memahami proses pembentukan hujan (Tokay dan Short, 1996). Dengan mengamati butiran hujan dari awal terbentuk hingga sampai ke tanah, maka dapat diketahui proses-proses apa saja yang telah 
dialami oleh butiran. Struktur vertikal RDSD juga dapat dimanfaatkan untuk mengkonversi data radar cuaca ke intensitas curah hujan (Das dan Maitra, 2016). Radar cuaca hanya memberikan nilai radar reflectivity $(Z)$ pada ketinggian di atas $2 \mathrm{~km}$ dan untuk mengkonversi nilai ini ke permukaan tanah maka harus diketahui struktur vertikal $Z$ (Coppens dan Haddad, 2000). Nilai $Z$ merupakan fungsi RDSD, maka dengan mengetahui struktur vertikal RDSD bisa didapatkan struktur vertikal $Z$ yang diperlukan dalam konversi data radar cuaca. Struktur vertikal RDSD dapat diamati menggunakan radar (Fukao dkk., 1985), videosonde (Takahashi dkk., 2001), dan precipitation occurrence sensor system (Sheppard dan Joe, 2008).

Sejak tahun 1980-an, radar atmosfer dengan gelombang pulsa telah dimanfaatkan untuk mengamati struktur vertikal RDSD. Di antara radar-radar tersebut adalah radar dengan ultra high frequency (UHF) dan very high frequency (VHF). Radar UHF bekerja pada frekuensi sekitar $915 \mathrm{MHz}$ sedangkan radar VHF bekerja pada frekuensi sekitar $50 \mathrm{MHz}$. Kedua radar ini dapat mendeteksi secara bersamaan sinyal hujan dan turbulen atmosfer (Fukao dkk., 1985; Wakasugi dkk., 1986). Penggunaan radar ini untuk mengamati butiran hujan telah dilakukan oleh beberapa peneliti sebelumnya seperti Wakasugi dkk. (1986) dan Gossard (1998). Kombinasi antara pengamatan radar UHF dan VHF juga bisa digunakan untuk mendapatkan struktur vertikal RDSD (Vonnisa dkk., 2014).

Kelemahan penggunaan radar pulsa baik dengan satu frekuensi maupun dengan dua frekuensi adalah tidak semua ketinggian dapat teramati terutama untuk ketinggian yang dekat dengan permukaan tanah. Hal ini disebabkan oleh adanya jarak minimal antara target dan radar sehingga tidak terjadi ambiguitas sinyal. Misalnya, ketinggian terendah yang dapat diamati oleh Equatorial Atmosphere Radar (EAR) dengan frekuensi $47 \mathrm{MHz}$ (VHF ) yang dipasang di Kototabang adalah $2 \mathrm{~km}$ di atas permukaan laut. Oleh karena itu, penggunaan EAR untuk mengamati RDSD hanya bisa dilakukan untuk ketinggian di atas $2 \mathrm{~km}$. Untuk mengatasi kekurangan radar pulsa, telah dikembangkan radar dengan gelombang kontinyu seperti Micro Rain Radar (MRR) (Peters dkk., 2002).

MRR adalah radar dengan sistem Frequency Modulated Continious Wave (FMCW) beroperasi pada frekuensi 24,1 GHz. Radar ini mempunyai daya puncak $50 \mathrm{~mW}$, resolusi waktu pengamatan 60 detik, dan resolusi ketinggian bervariasi dengan total range gate 31. Misalnya, jika resolusi ketinggian adalah $150 \mathrm{~m}$, maka ketinggian maksimum yang dapat dijangkau radar adalah $4650 \mathrm{~m}$ (31 x $150 \mathrm{~m})$.

Penelitian ini meneliti tentang struktur vertikal RDSD di Kototabang $(0,200$ LS; 100,320 BT; $865 \mathrm{~m}$ di atas permukaan laut) dengan menggunakan MRR. Penelitian tentang RDSD di Kototabang telah dilakukan oleh beberapa peneliti sebelumnya (Kozu dkk., 2005; Marzuki dkk., 2009; 2010a; 2012; 2013a; 2013b; 2016) tetapi sebagian besar penelitian tersebut adalah tentang RDSD di permukaan tanah. Untuk struktur vertikal RDSD telah dilakukan penelitian oleh Kozu dkk. (2005) dan Marzuki dkk. (2010a) dengan menggunakan EAR dan Vonnisa dkk. (2014) dengan menggunakan kombinasi EAR dan Boundary Layer Radar (BLR). Kedua peneliti ini menggunakan radar pulsa sehingga butiran hujan di bawah 2 $\mathrm{km}$ belum teramati. Oleh karena itu, pada penelitian ini akan diteliti tentang struktur vertikal RDSD menggunakan MRR sehingga semua ketinggian yang belum teramati dapat teramati.

\section{METODE}

MRR adalah radar yang bekerja secara vertikal dan menyediakan parameter hujan yang diukur menggunakan prinsip doppler (Peters dkk., 2002). Untuk mengambil parameter yang diperlukan seperti RDSD, diameter butiran, $R, Z$, dan $L W C$, digunakan fungsi grep yang ada pada software Cygwin. Setelah didapat data yang diperlukan, dilakukan pengolahan data dengan Matlab. Untuk memantau kinerja dari MRR, diplot nilai RDSD dari Parsivel dan MRR dan nilai total rainfall dan rainfall rate dari ORG dan MRR sebagai pembanding. RDSD dikelompokkan berdasarkan 6 kelas intesitas curah hujan mengikuti kelas dalam Tokay dan Short (1996), kemudian dirata-ratakan. Hal ini akan memberikan informasi awal tentang perbedaan RDSD untuk setiap ketinggian. Untuk melihat karakteristik RDSD, RDSD dimodelkan dengan distribusi gamma sebagai berikut: 


$$
N(D)=N_{T} \frac{\Lambda^{m+1} D^{m}}{\Gamma(m+1)} \exp (-\Lambda D)
$$

dimana $N(D)$ adalah fungsi RDSD (mm-1 m -3 ), $N_{T}$ adalah parameter intercept dengan satuan $\mathrm{m}^{-3}, m$ adalah parameter bentuk (shape) dan $\Lambda$ merupakan parameter slope dari distribusi dalam satuan $\mathrm{mm}^{-1}$. Parameter gamma $\operatorname{RDSD}\left(m, N_{T}\right.$, dan $\Lambda$ ) dihitung menggunakan metode momen. Metode momen dikembangkan berdasarkan prinsip bahwa semua parameter hujan merupakan fungsi RDSD yang secara umum dapat ditulis sebagai berikut:

$$
M_{i}=\int_{0}^{\infty} N(D) D^{i} d D
$$

dimana $M_{i}$ merupakan momen RDSD. Dalam bentuk fungsi gamma Persamaan (2a) dapat ditulis sebagai (Kozu dan Nakamura, 1991):

$$
M_{i}=N_{T} \frac{\Gamma(i+m+1)}{\Lambda^{i} \Gamma(m+1)}
$$

Untuk menghitung parameter RDSD pada Persamaan 1 berdasarkan Persamaan $2 b$, dapat dipilih kombinasi tiga buah momen dari $i=0$ hingga $i=6$ dalam dalam penelitian ini digunakan momen ke-3, 4 dan 6 (Kozu dan Nakamura, 1991; Marzuki dkk., 2010b; 2012). Momen ke-3, 4 dan 6 sering dipilih karena tiga momen ini mendekati kepada parameter fisis hujan yaitu $M 3 \cong L W C, M 4 \cong R$ dan $M 6 \cong Z$. Dengan mengkombinasikan ketiga momen RDSD, didapatkan persamaan berikut:

$$
\begin{gathered}
N_{T}=\frac{\Lambda^{3} M_{3} \Gamma(m+1)}{\Gamma(m+4)} \\
\Lambda=\frac{(m+4) M_{3}}{M_{4}}=\frac{m+4}{D_{m}} \\
m=\frac{11 G-8+[G(G+8)]^{\frac{1}{2}}}{2(1-G)} \\
G=\frac{M_{4}^{3}}{M_{3}^{2} M_{6}} \\
D_{m}=\frac{M_{4}}{M_{3}}
\end{gathered}
$$

dimana $\mathrm{D}_{\mathrm{m}}$ adalah mass-weight mean diameter.

Perhitungan dilakukan untuk semua ketinggian sehingga dapat diamati perubahan parameter dengan perubahan ketinggian. Perubahan parameter terhadap ketinggian diamati dengan membuat grafik parameter untuk setiap intesitas curah hujan. Tahap terakhir yang dilakukan adalah menghitung persamaan $Z-R$. Persamaan $Z-R$ dihitung dengan menggunakan regresi linear dalam skala logaritmik.

\section{HASIL DAN DISKUSI}

\subsection{Pengecekan Kinerja MRR}

Pengecekan kinerja MRR dilakukan dengan membandingkan hasil pengamatan MRR dengan Parsivel dan ORG. Gambar 1 memperlihatkan perbandingan nilai RDSD dari MRR pada ketinggian $150 \mathrm{~m}$ dengan RDSD dari Parsivel pada tanggal 17 Oktober 2014 pada jam 19.51-19.59 WIB. Data MRR pada ketinggian 150 m merupakan data yang paling dekat dengan permukaaan tanah. Data yang akan dianalisis di dalam penelitian ini adalah data selama tahun 2012 tetapi data pengamatan Parsivel pada tahun tersebut tidak tersedia maka untuk pengecekan kinerja MRR digunakan data tahun 2014 yang telah diolah sebelumnya oleh Chandra dkk. 
(2015). Dari sembilan menit data yang dibandingkan terlihat bahwa secara umum MRR menghasilkan pola RDSD yang sama dengan Parsivel. Sedikit perbedaan teramati pada butiran yang kecil dimana konsentrasi butiran dari MRR lebih tinggi dibandingkan dengan Parsivel. Pada sisi lain, pada butiran hujan yang besar konsentrasi dari MRR lebih kecil dibandingkan dengan Parsivel. Perbedaan ini dianggap lazim mengingat kedua instrumen mempunyai prinsip kerja dan luas daerah pengamatan yang berbeda.
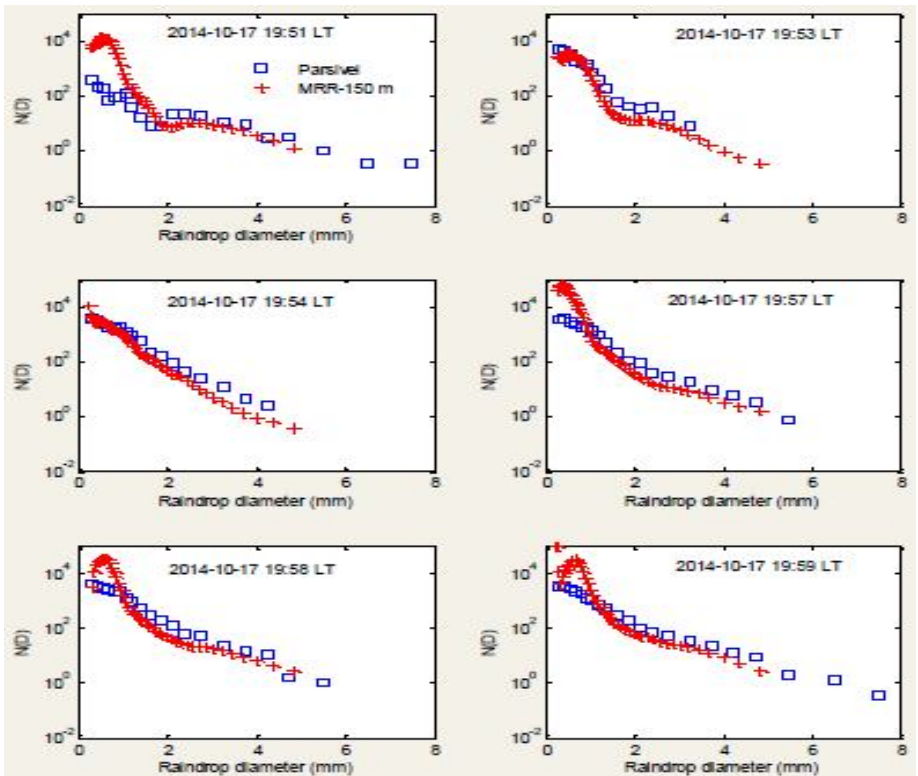

Gambar 1 Perbandingan pengukuran RDSD oleh MRR dan Parsivel pada ketinggian $150 \mathrm{~m}$ pada tanggal 17 Oktober 2014.

Gambar 2 memperlihatkan perbandingan intensitas curah hujan (rainfall rate) dan total rainfall dari ORG dan MRR selama Januari-Mei 2012. Data ORG di Kototabang hanya tersedia hingga Mei 2012 sehingga untuk pengecekan kinerja MRR digunakan data selama Januari-Mei 2012. Intensitas curah hujan dan total curah hujan dari MRR memperlihatkan kecocokan yang tinggi dengan ORG yang ditandai dengan koefisien regresi dari persamaan regresi sekitar 0,98 dan 0,86 . Intensitas curah hujan yang dihasilkan oleh ORG sedikit lebih tinggi dibandingkan dengan MRR yang terlihat dari persamaan regresi $y=1,1 x+0,11$. Das dan Maitra (2016) juga mengamati intensitas curah hujan dari MRR sedikit lebih rendah dari yang didapatkan optical rain gauge. Hal ini konsisten dengan RDSD (Gambar 1) dimana konsentrasi butiran hujan yang besar di tanah dari Parsivel lebih tinggi dibandingkan dengan MRR.
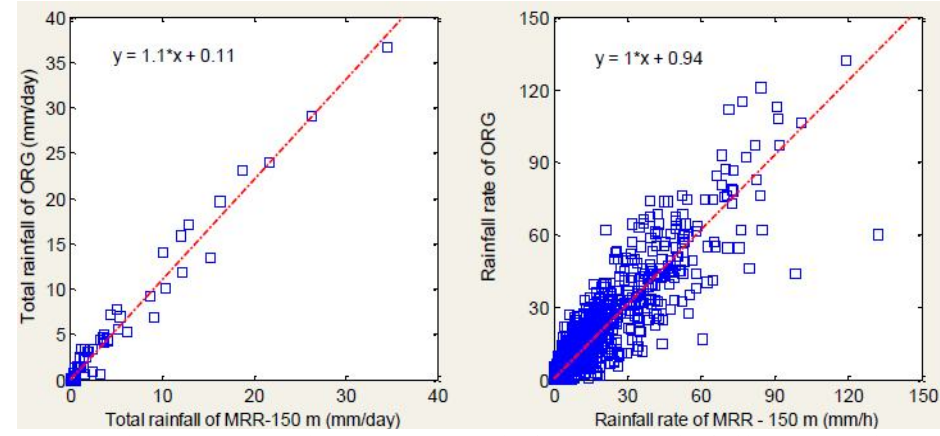

Gambar 2 Perbandingan pengukuran total rainfall dan rainfall rate dari ORG dan MRR pada ketinggian $150 \mathrm{~m}$ selama Januari-Mei 2012.

\subsection{RDSD Rata-Rata}

Gambar 3 memperlihatkan perbandingan RDSD rata-rata di Kototabang untuk 6 kelas intensitas curah hujan, dimulai dari hujan sangat ringan atau very light rain $(R 0,1 \leq R<1$ $\mathrm{mm} / \mathrm{h})$ sampai hujan ekstrem atau extreme $(R \geq 20 \mathrm{~mm} / \mathrm{h})$. Untuk intensitas curah hujan sangat 
ringan (Gambar 3a), RDSD hanya terdiri dari butiran $<2 \mathrm{~mm}$. Selain itu, pertumbuhan butiran hujan juga tidak signifikan yang ditandai dengan hampir konstannya distribusi vertikal RDSD dari $3 \mathrm{~km}$ ke tanah. Semakin besar intensitas curah hujan maka semakin besar pula butiran hujan yang sampai ke tanah.
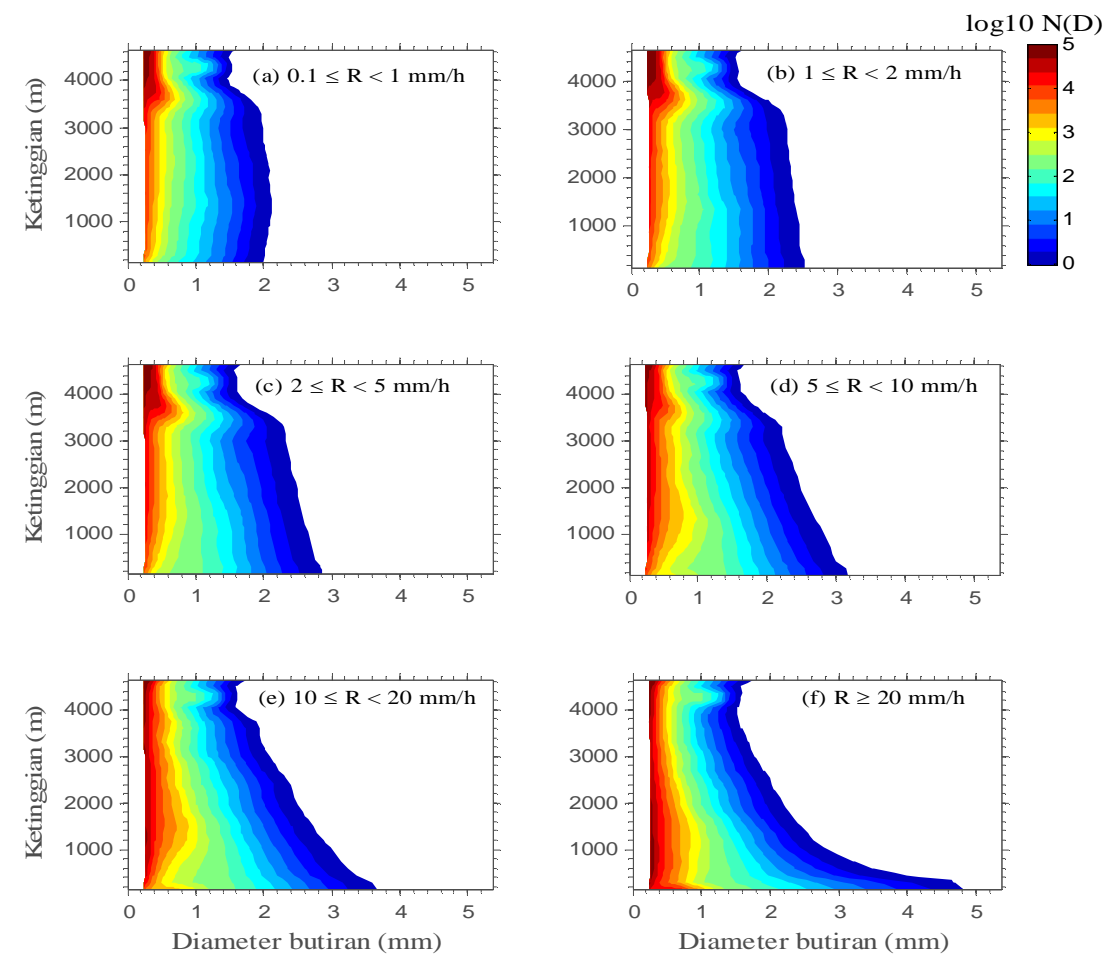

Gambar 3 RDSD rata-rata pada 6 kelas intensitas curah hujan. (a) Sangat ringan (very light)

(b) Ringan (light) (c) Sedang (moderate) (d) Deras (heavy) (e) Sangat Deras (very heavy)

(f) Ekstrem (extreme).

Pada intensitas yang sangat tinggi (Gambar 3f) pertumbuhan butiran hujan sangat signifikan dimana dari sekitar $2 \mathrm{~mm}$ pada ketinggian 4,65 km menjadi $5 \mathrm{~mm}$ di ketinggian 150 $\mathrm{m}$ dari permukaan tanah. Pertumbuhan RDSD ini disebabkan oleh proses tumbukan yang menyebabkan penggabungan (coalescence). Pada ketinggian sekitar 3,4 km di atas permukaan tanah, ukuran butiran hujan yang berkonsentrasi tinggi agak besar yang membentuk sebuah puncak hingga diameter $0,5 \mathrm{~mm}$. Lapisan ini disebut melting layer dimana partikel es mulai mencair menjadi butiran hujan. Pada lapisan ini udara mulai bertemperatur besar dari $0^{\circ} \mathrm{C}$. Melting layer hanya teramati pada hujan dengan intensitas kurang dari $10 \mathrm{~mm} / \mathrm{h}$ (Tokay dan Short, 1996). Hujan dengan melting layer biasanya disebut hujan stratiform dan hujan dengan tanpa melting layer disebut hujan konvektif (Marzuki dkk., 2010a; Marzuki dkk., 2013b; 2016).

\subsection{Parameter RDSD}

Untuk lebih membahas Gambar 3 secara kuantitatif, maka parameter RDSD untuk setiap gambar dihitung dengan metode momen pada Persamaan (3-7). Distribusi parameter untuk setiap ketinggian diperlihatkan pada Gambar 4. Secara umum dapat dilihat bahwa nilai shape parameter $(m)$ di bawah melting layer meningkat dengan penurunan ketinggian yang menandakan terjadi penurunan konsentrasi butiran kecil dan peningkatan konsentrasi butiran yang besar yang terlihat dengan jelas pada Gambar 3. Pola $m$ ini konsisten dengan distribusi vertikal $D_{m}$. Peningkatan konsentrasi butiran hujan yang besar serta proses evaporasi akan menurunkan jumlah butiran dari mulai terbentuk hingga ke tanah yang berdampak kepada penurunan nilai $N_{T}$ dengan penurunan ketinggian (Gambar 4c).

Pada ketinggian di atas $4 \mathrm{~km}$ nilai dari parameter $N_{T}$ dan $D_{m}$ untuk setiap kelas intensitas curah hujan relatif sama. Namun, di bawah ketinggian $4 \mathrm{~km}$ nilai parameter $N_{T}$ dan $D_{m}$ berbeda untuk setiap kelas intensitas. Hal ini menunjukkan bahwa di bawah melting layer 
tingkat pertumbuhan butiran hujan berbeda-beda bergantung kepada intensitas curah hujan. Hal ini konsisten dengan pola RDSD pada Gambar 3.

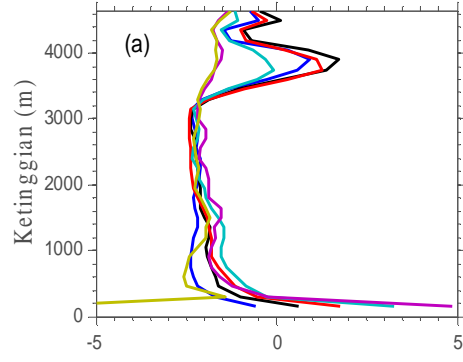

Shape parameter (m)

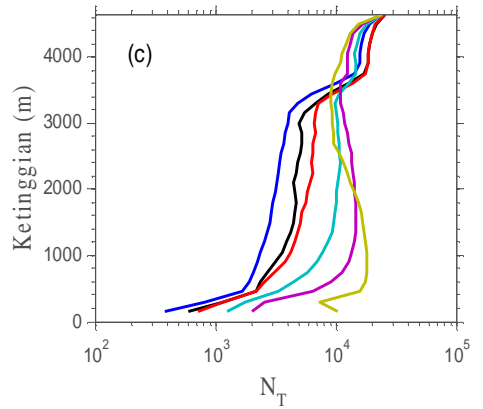

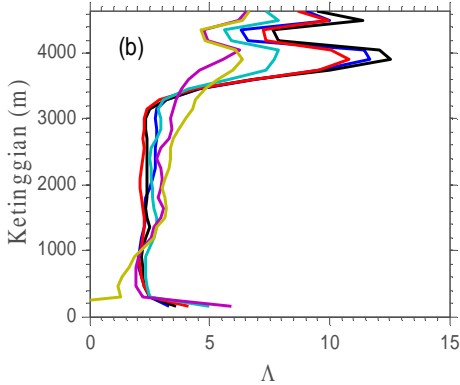

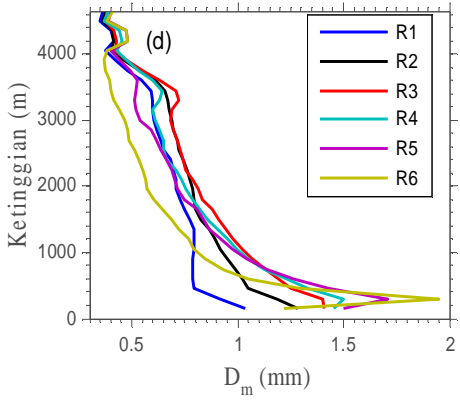

Gambar 4 Perbandingan parameter gamma dengan ketinggian untuk kelas intensitas curah hujan (a) Shape Parameter (m), (b) $\Lambda$, (c) $N_{T}$ dan (d) $D m$

\subsection{Profil Rata-rata Parameter Hujan}

Parameter hujan seperti rainfall rate $(R)$, radar reflektivitas $(Z)$, Liquid Water Content (LWC) merupakan fungsi RDSD. Oleh karena itu, perubahan RDSD terhadap ketinggian sebagaimana teramati pada Gambar 3 akan mempengaruhi distribusi vertikal $R, Z$ dan $L W C$. Gambar 5a menunjukkan profil rata-rata $R$ untuk beberapa intensitas curah hujan yang menunjukkan kemiringan negatif terhadap ketinggian, namun pada intensitas curah hujan ekstrem mempunyai kemiringan negatif yang curam pada ketinggian dibawah $4 \mathrm{~km}$. Pada kelas intensitas curah hujan sangat ringan, ringan dan sedang $R$ relatif sama pada setiap ketinggian kecuali pada rentang 3,4 km-4 km. Perubahan nilai dari $\mathrm{R}$ ini sama dengan perubahan RDSD rata-rata (Gambar 3) pada setiap intensitas curah hujan dimana pada intensitas curah hujan <10 $\mathrm{mm} / \mathrm{h}$ juga menunjukkan perubahan yang relatif sama pada setiap ketinggian kecuali pada daerah melting layer, dan pada intensitas curah hujan $>10 \mathrm{~mm} / \mathrm{h}$ semakin besar dengan menurunnya ketinggian.

Gambar $5 \mathrm{~b}$ adalah profil rata-rata $Z$ untuk beberapa intensitas curah hujan. Melting layer pada profil $Z$ teramati pada ketinggian sekitar 3,4 km untuk intensitas curah hujan sangat ringan hingga sedang dan hal ini menandakan hujan pada intensitas hujan ini merupakan tipe stratiform. Pada intensitas curah hujan yang deras puncak dari $Z$ relatif kecil pada ketinggian melting layer ditandai bahwa beberapa kasus hujan mempunyai struktur melting layer walaupun kebanyakan dari hujan adalah tipe konvektif, intinya tipe hujan ini hujan yang terjadi selama periode transisi dari hujan stratiform dan konvektif. Namun, pada intensitas curah hujan sangat deras dan ekstrem tidak terdapat puncak dan ini menunjukkan hujan konvektif.

Profil $Z$ memperlihatkan kemiringan negatif terhadap ketinggian dan kemiringan meningkat dengan meningkatnya intensitas curah hujan. Hal ini juga sama dengan perubahan RDSD yang terdapat pada Gambar 3. Namun pada ketinggian sekitar $300 \mathrm{~m}$ menunjukkan pengurangan kemiringan dan pada intensitas curah hujan sangat ringan ditandai kemiringan positif. Hal ini bisa terjadi karena adanya evaporasi, akibat evaporasi ini butiran berdiameter kecil tidak bisa mencapai tanah. Pada intensitas curah hujan ekstrem memiliki kemiringan negatif yang curam yang juga diperlihatkan pada Gambar 3f. 
Profil rata-rata $L W C$ diperlihatkan pada Gambar 5c. Sama dengan parameter lainnya, semakin besar nilai intensitas curah hujan maka nilai dari $L W C$ juga akan semakin besar. Namun, tetap pada intensitas curah hujan ekstrem memiliki perbedaan yaitu mempunyai perubahan yang besar untuk setiap ketinggiannya terutama pada ketinggian yang dekat dengan permukaan tanah yang menunjukkan kemiringan positif. Hal ini sama dengan Gambar 3 pada konsentrasi ukuran butiran yang tinggi.
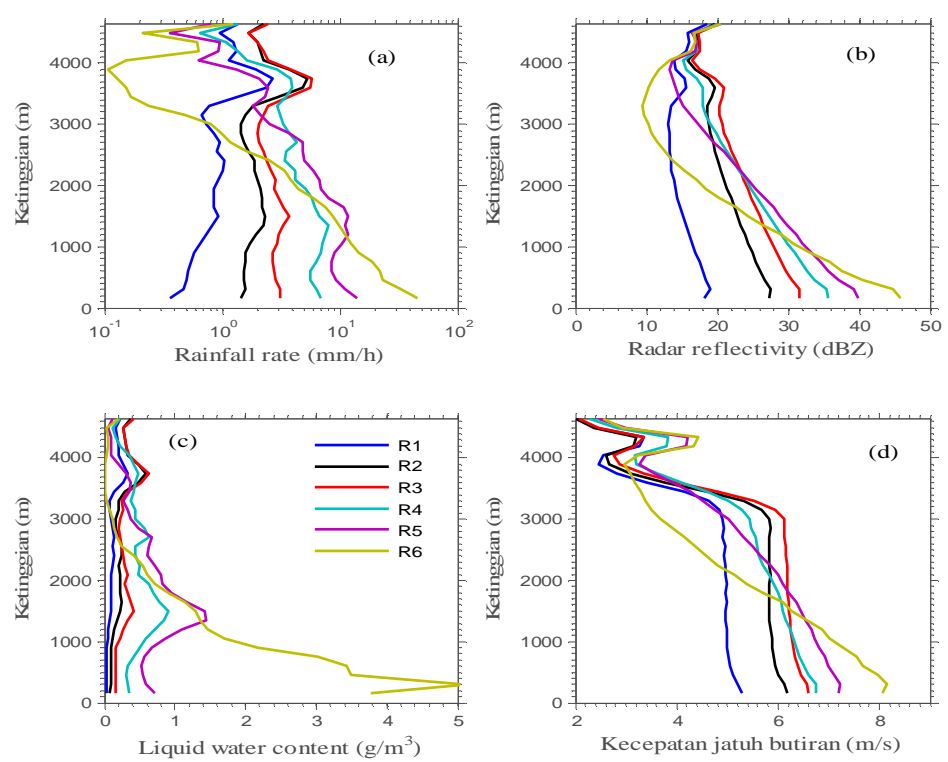

Gambar 5 Perbandingan parameter hujan dengan ketinggian untuk 6 kelas intensitas curah hujan (a) Rainfall rate ,(b) Radar reflectivity, (c) Liquid Water Content dan

(d) Kecepatan jatuh butiran

Gambar 5d memperlihatkan profil rata-rata kecepatan jatuh butiran hujan. Profil ratarata kecepatan jatuh butiran sangat bermanfaat untuk menunjukkan ketinggian melting layer yang dapat dilihat dari kemiringan negatif yang curam di bawah melting layer. Kemiringan negatif yang curam ini tergantung kepada campuran es dan air. Dengan demikian berdasarkan Gambar 5d ketinggian melting layer di Kototabang adalah sekitar 3,4 km di atas permukaan tanah.

\subsection{Parameter RDSD per menit}

Untuk melihat karakteristik RDSD maka pada bagian ini akan dibahas parameter gamma dari data yang terekam setiap menit. Gambar 6 memperlihatkan histogram distribusi parameter gamma $\left(D m, m, \log 10 N_{T}\right)$ dari hujan di Kototabang untuk beberapa ketinggian. Data diplot dari ketinggian $3300 \mathrm{~m}$ karena pada ketinggian ini kemungkinan RDSD sudah tidak tercampur dengan butiran es. Gambar 6a menunjukkan bahwa semakin rendah ketinggian maka nilai $D_{m}$ akan semakin besar, ini dapat dilihat dari perubahan puncak pada histogram, puncak ini merupakan butiran hujan yang dominan. Hal ini konsisten dengan nilai rata-rata pada Gambar 4. Semakin besarnya nilai $D_{m}$ dengan penurunan ketinggian mengindikasikan bahwa butiran hujan yang berdiameter besar meningkat dengan penurunan ketinggian. Pola yang sama juga teramati untuk parameter $\mathrm{m}$. Namun, pada ketinggian $150 \mathrm{~m}$ nilai $m$ lebih rendah dibandingkan nilai $m$ pada ketinggian $600 \mathrm{~m}$. Ini menandakan bahwa terjadi perubahan bentuk RDSD dari ketinggian $600 \mathrm{~m}$ ke $150 \mathrm{~m}$. Butiran pada ketinggian $600 \mathrm{~m}$ lebih besar dibandingkan ketinggian $150 \mathrm{~m}$, ini disebabkan karena butiran kembali pecah. Pola parameter $\Lambda$ berkebalikan dengan Dm karena $\Lambda \cong 1 / D_{m}$.

Gambar $6 \mathrm{c}$ menunjukkan histogram nilai $\log 10 N_{T}$ untuk beberapa ketinggian. Hal ini menunjukkan bahwa total jumlah butiran hujan semakin berkurang dengan penurunan ketinggian. Hal ini terjadi karena adanya proses tumbukan-penggabungan yang menyebabkan jumlah total butiran berkurang dengan penurunan ketinggian. Selain itu, penurunan $N_{T}$ juga bisa 
terjadi karena penguapan yang terjadi pada butiran, terutama pada butiran yang berukuran kecil. Pada ketinggian $150 \mathrm{~m}$ nilai $N_{T}$ lebih besar dari $600 \mathrm{~m}$. Hal ini mungkin disebabkan karena butiran yang berdiameter besar kembali pecah dipermukaan tanah yang terlihat juga dengan penurunan nilai $\mathrm{m}$.

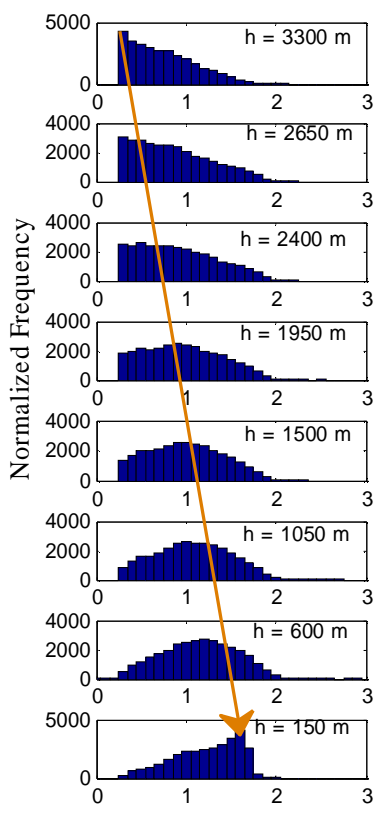

(a) $\mathrm{Dm}$

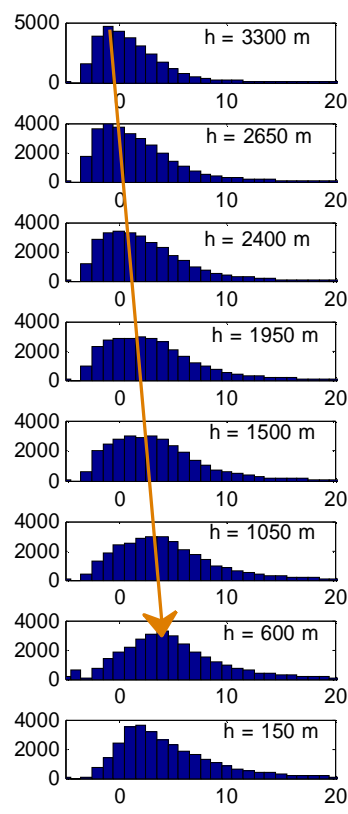

(b) $\mathrm{m}$

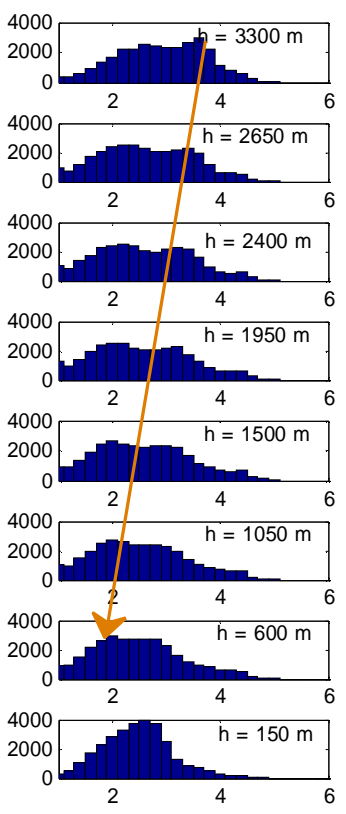

(c) NT

Gambar 6 Distribusi frekuensi parameter gamma RDSD di Kototabang (a) $D_{m}$ (b) $m$ (c) $\log 10 N_{T}$

\subsection{Persamaan Z-R}

Salah satu aplikasi terpenting dari data RDSD adalah untuk membentuk persamaan $Z-R$ $\left(Z=A R^{b}\right)$ yang dipakai untuk mengkonversi nilai $Z$ dari radar meteorologi menjadi intensitas curah hujan $(R)$. Secara umum, persamaan $Z-R$ yang digunakan didapatkan dengan fitting/regresi dimana sumbu y adalah nilai $Z$ dan sumbu x adalah untuk nilai $R$. Namun, pada penelitian ini digunakan metode $R-Z$ dimana sumbu-y untuk $R$ dan sumbu-x untuk $Z$. Hal ini digunakan karena parameter yang diketahui oleh radar adalah $Z$ dan yang ingin kita dapatkan adalah $R$.
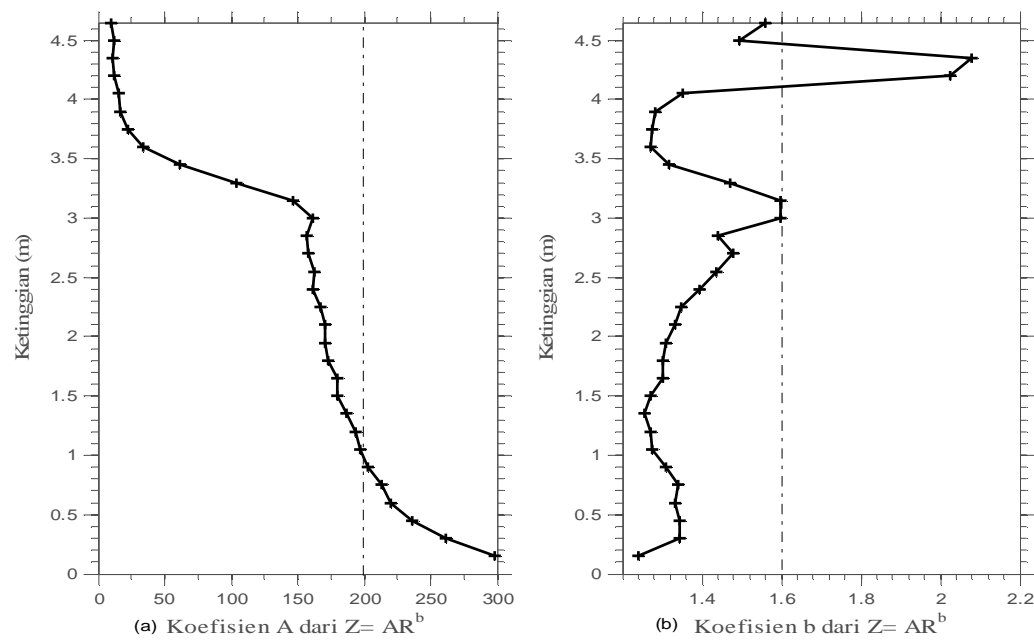

Gambar 7 Koefisien dari persamaan $Z=A R^{b}$, garis vertikal putus-putus menandakan koefisien dari persamaan MP $\left(\mathrm{Z}=200 \mathrm{R}^{1,6}\right)$ (a) Koefisien A dari $Z=A R^{b}$

(b) Koefisien b dari $Z=A R^{b}$ 
Profil vertikal koefisien persamaan $Z-R$ dapat dilihat pada Gambar 7. Persamaan Z-R pada umumnya digunakan pada radar cuaca adalah persamaan Marshall-Palmer (MP) yaitu $Z=200 R^{1,6}$, yang ditandai dengan garis putus-putus pada Gambar 7. Hasil penelitian ini memperlihatkan bahwa koefisien A tidak konstan dengan perubahan ketinggian dimana semakin dekat ke permukaan tanah nilai A semakin besar. Hal ini berbeda dengan karakteristik dengan koefisien $\mathrm{b}$ dari 1,5-3 $\mathrm{km}$ nilainya semakin kecil dengan penurunan ketinggian dan dari 0,3-1,5 $\mathrm{km}$ nilainya meningkat dengan penurunan ketinggian. Dengan demikian, penggunaan $Z-R$ yang sama untuk setiap ketinggian dalam mengkonversi data radar cuaca dapat menyebabkan ketidakakuratan hasil konversi.

Tabel 1 memperlihatkan persamaan $Z-R$ untuk beberapa ketinggian. Tokay dkk. (2009) mendapatkan distribusi vertikal persamaan $Z-R$ dari data MRR untuk beberapa ketinggian dari $150 \mathrm{~m}$ sampai $500 \mathrm{~m}$ di Wallops Flight Facility (WFF) NASA di Virginia. Mereka mendapatkan nilai Z-R untuk beberapa ketinggian yaitu $Z=323 R^{1,49}$ untuk $150 \mathrm{~m}, Z=294 R^{1,57}$ untuk $300 \mathrm{~m}$ dan $Z=282 R^{1,62}$ untuk $450 \mathrm{~m}$. Hasil yang didapatkan dari penelitian ini secara umum konsisten dengan yang didapatkan oleh Tokay dkk. (2009) dimana koefisien A dan b meningkat dengan penurunan ketinggian. Peningkatan koefisien A ini konsisten dengan peningkatan jumlah butiran hujan berukuran besar dengan penurunan ketinggian (Gambar 3) karena Z dan R lebih dipengaruhi oleh butiran yang besar (Marzuki dkk., 2010a; 2013a; 2013b; 2016).

Tabel 1 Persamaan $Z-R$ untuk beberapa ketinggian di Kototabang

\begin{tabular}{cc}
\hline Ketinggian $(\mathbf{m})$ & $\mathbf{Z}$ \\
\hline 150 & $\mathrm{Z}=298 \mathrm{R}^{1,24}$ \\
300 & $\mathrm{Z}=261 \mathrm{R}^{1,34}$ \\
450 & $\mathrm{Z}=236 \mathrm{R}^{1,34}$ \\
600 & $\mathrm{Z}=219 \mathrm{R}^{1,33}$ \\
\hline
\end{tabular}

\section{KESIMPULAN}

Penelitian ini memperlihatkan bahwa MRR yang terpasang di Kototabang berfungsi dengan baik. Korelasi yang didapatkan dari persamaan regresi antara intensitas curah hujan dan total curah hujan harian yang didapatkan oleh MRR dan ORG adalah sekitar 0,98 dan 0,86. Selain itu, RDSD dari MRR dengan Parsivel juga memperlihatkan nilai dan pola yang hampir sama. Penelitian ini memperlihatkan bahwa RDSD di Kototabang mengalami pertumbuhan yang sangat kuat dalam kolom hujan $(4,6-0,15 \mathrm{~km})$. Terjadi peningkatan konsentrasi butiran hujan dengan ukuran yang signifikan dari ketinggian 4,65 km hingga $0,15 \mathrm{~km}$. Peningkatan konsentrasi butiran hujan berukuran besar ini mempengaruhi peningkatan parameter hujan terhadap penurunan ketinggian yang menyebabkan peningkatan koefisien $\mathrm{A}\left(Z=A R^{b}\right)$ terhadap penurunan ketinggian. Hal ini mengindikasikan penggunaan persamaan $Z-R$ yang konstan untuk setiap ketinggian bagi radar meteorologi di kawasan tropis khususnya Sumatera Barat tidak tepat.

\section{DAFTAR PUSTAKA}

Chandra, R., Marzuki, Vonnisa, M., Hashiguchi, H., 2015, Perbandingan Variasi Diurnal Distribusi Ukuran Butiran Hujan di Padang dan Kototabang, Prosiding Seminar Nasional Fisika Universitas Andalas (SNFUA), hal. 158-163.

Coppens, D. dan Haddad, Z.S., 2000, Effect of Raindrop Size Distribution Variationson Microwave Brightness Temperature Calculation, Journal of Geophysical Research, Vol. 105, No. 19, hal. 483-489.

Das, S. dan Maitra, A., 2016, Vertical Profile of Rain : Ka Band Radar Observations at Tropical Locations, Journal of Hydrology, Vol. 534, hal. 31-41.

Fukao, S., Wakasugi, K., Sato, T., Morimoto, S., Tsuda, T., Hirota, I., Kimura, I., dan Kato, S., 1985, Direct Measurement of Air and Precipitation Particle Motion by VHF Doppler Radar, Nature, Vol. 316, hal. 712-714.

Gossard, E. E., 1998, Measuring Drop-Size Distribution in Cloud with a Clear-Air-Sensing Doppler Radar, Journal of Atmospheric and Oceanic Technology, Vol. 5, hal. 640-649. 
Jameson, A.R. dan Kostinski, A.B., 2001, What is a Raindrop Size Distribution, Bulletin of American Meteorological Society, Vol. 82, No.6, hal. 1169- 1177.

Joss, J. dan Waldvogel, A., 1969, Raindrop Size Distribution and Sampling Size Errors, Journal of the Atmospheric Science, Vol. 26, hal. 566-569.

Kruger, A. dan Krajewski, W.F., 2002, Two-dimensional Video Disdrometer: A Description, Journal of Atmospheric and Oceanic Technology, Vol. 19, hal. 602-617.

Kozu, T. dan Nakamura, K., 1991, Rainfall Parameter Estimation from Dual-Radar Measurements Combining Reflectivity Profile and Path-Integrated Attenuation, Journal of Atmospheric and Oceanic Technology, Vol. 8, hal. 259 - 271.

Kozu, T., Shimomai, T., Akramin, Z., Marzuki, Shibagaki, Y. dan Hashiguchi, H., 2005, Intraseasonal Variation of Raindrop Size Distribution at Koto Tabang, West Sumatra, Indonesia, Geophysical Research Letter, Vol. 32, L07803, doi: 10.1029/2004GL022340.

Loffler-Mang, M. dan Joss J., 2000, An Optical Disdrometer for Measuring Size and Velocity of Hydrometeors, Journal of Atmospheric and Oceanic Techology, Vol. 17, hal. $130-$ 139.

Marzuki, M., Kozu, T., Shimonai, T., Randeu, W.L., Hashiguchi, H. Dan Shibagaki, Y., 2009, Diurnal Variation of Rain Attenuation Obtained from Measurement of Raindrop Size Distribution in Equatorial Indonesia, IEEE Transaction on Antennas and Propagation, Vol. 57, No. 4, hal. 1191-1196.

Marzuki, Kozu, T., Shimomai, T, Hashiguchi, H., Randeu, W.L. dan Vonnisa, M., 2010a, Raindrop Size Distribution of Convective Rain over Equatorial Indonesia During the First CPEA Campaign, Atmospheric Research, Vol. 96 hal. 645 - 655.

Marzuki, Randeu, W. L., Kozu, T., Shimomai, T., Schoenhuber, M. and Hashiguchi, H, 2012, Estimation of raindrop size distribution parameters by maximum likelihood and Lmoment methods: Effect of discretization, Atmospheric Research, Vol. 112, hal. 1-11.

Marzuki, M., Randeu, W.L., Kozu, T., Hashiguchi, H. dan Schonhuber M, 2013a, Raindrop Axis Ratio, Fall Velocities and Size Distribution over Sumatra from 2D - Video Disdrometer Measurement, Atmospheric Research, Vol. 119, hal. 23-37.

Marzuki, M., Randeu, W.L., Kozu, T., Hashiguchi, H. dan Schonhuber M, 2013b, Raindrop Axis Ratio, Fall Velocities and Size Distribution over Sumatra from 2D - Video Disdrometer Measurement, Atmospheric Research, Vol. 119, hal. 23-37.

Marzuki, Hashiguchi, H., Kozu, T., Shimomai, T., Shibagaki, Y., Takahashi, Y., 2016, Precipitation Microstructure in Different Madden-Julian Oscillation Phases over Sumatra, Atmospheric Research, Vol. 168, hal. 121-138.

Peters, G., Fischer, B. dan Andersson, T., 2002, Rain observations with avertically looking Micro Rain Radar (MRR), Boreal Environmetal, Vol.7, hal. 353-362.

Sheppard, B.E. dan Joe, P.I., 2008, Performance of the Precipitation Occurence Sensor System as a Precipitation Gauge, Journal of Atmospheric and Technology, Vol. 25, hal. 196212.

Takahashi, T., Yamaguchi, N. dan Kawano, T., 2001, Videosonde Observation of Torrential Rain During Baiu Season, Journal of Atmospheric Research, Vol. 58, hal. 205-228.

Tokay, A. dan Short, D.A., 1996, Evidence from Tropical Raindrop Spectra of the Origin of Rain from Statiform Versus Convective Clouds, Journal Applied Meteorology, Vol. 35, hal 355- 371.

Tokay, A., Hartmann, P., Battaglia, A., Gage, K.S., Clark, W.L., Williams, C.R., 2009, A Field Study of Reflectivity and Z-R Relations Using Vertically Pointing Radars and Disdrometers, Journal of Atmospheric and Oceanic Technology, Vol. 26, hal. 11201134.

Vonnisa, M., Kozu, T. dan Shimonai, T., 2014, Pengembangan Metode Dual-Frekuensi untuk Mengamati Struktur Vertikal Raindrop Size Distribution (DSD) di Kototabang, Jurnal Ilmu Fisika,Vol. 6, hal. 52-58.

Wakasugi, K., Mizutani, A., Matsuo, M., Fukao, S. dan Kato, S., 1986, A Direct Method for Deriving Drop-size Distribution and Vertical Air Velocities from VHF Doppler Radar Spectra, Journal of Atmospheric and Oceanic Technology, Vol. 3, hal. 623-629. 